\title{
Summary of the NACI Update on Immunization in Pregnancy with Tetanus Toxoid, Reduced Diphtheria Toxoid and Reduced Acellular Pertussis (Tdap) Vaccine
}

\author{
J Brophy ${ }^{1}$, O Baclic ${ }^{2}$, MC Tunis ${ }^{2}$ on behalf of the National Advisory Committee on Immunization \\ $(\mathrm{NACl})^{\star}$
}

\begin{abstract}
Background: In Canada, pertussis is an endemic and cyclical disease, with peaks occurring at two- to five-year intervals. Although pertussis incidence varies by age group, unvaccinated or undervaccinated infants are at greatest risk of infection and associated complications. Since the last National Advisory Committee on Immunization (NACI) recommendations published in 2014, new evidence on the safety and effectiveness of tetanus toxoid, reduced diphtheria toxoid and reduced acellular pertussis (Tdap) vaccine administration in pregnancy has become available.
\end{abstract}

Objective: To provide guidance on maternal immunization in pregnancy as a strategy to reduce disease incidence and severe outcomes (defined as hospitalization or death) from pertussis infection in infants less than 12 months of age.

Methods: The $\mathrm{NACl}$ reviewed evidence on the burden of disease in Canada, vaccine safety and immunogenicity and vaccine effectiveness in jurisdictions that have implemented maternal immunization programs. A total of 59 articles were identified, retrieved and included in the literature review to inform this statement.

Results: In the majority of reviewed studies, post immunization increases in antibody levels resulted in more than $90 \%$ of women achieving anti-PT levels greater than or equal to $10 \mathrm{lU} / \mathrm{ml}$ one month following immunization. In infants, maternal immunization was found to result in increased pertussis antibody concentrations. In the majority of studies, following the receipt of the fourth diphtheria, tetanus and pertussis (DTaP) dose after 15 months of age, no statistically significant differences in antibody levels and avidity were observed between infants whose mothers received Tdap in pregnancy and those whose mothers did not receive Tdap in pregnancy. No major maternal or infant safety issues, including pregnancy outcomes, were reported in the reviewed literature. Effectiveness of maternal Tdap immunization in pregnancy was estimated to be over $90 \%$ against pertussis in infants younger than two months of age, with no deaths observed among infants whose mothers received Tdap prior to 36 weeks of pregnancy. Maternal immunization with Tdap in pregnancy also resulted in a reduction in infant disease severity and hospitalization. Vaccine effectiveness was also reported to persist after the receipt of the first three DTaP doses, with immunization in pregnancy resulting in additional protection of up to $70 \%$ in children whose mothers received Tdap in pregnancy.

Conclusion: There is now strong evidence to support the $\mathrm{NACl}$ recommendation that immunization with Tdap vaccine should be offered in every pregnancy. This is ideally administered between 27 and 32 weeks of gestation but evidence also supports providing maternal Tdap over a wider range of gestational ages, from 13 weeks up to the time of delivery, in view of programmatic and unique patient considerations.

\section{Affiliations}

${ }^{1}$ Children's Hospital of Eastern Ontario, Ottawa, ON

${ }^{2}$ Centre for Immunization and Respiratory Infectious Diseases, Public Health Agency of Canada, Ottawa, ON

*Correspondence: naci-ccni@ phac-aspc.gc.ca
Suggested citation: Brophy J, Baclic O, Tunis MC on behalf of the National Advisory Committee on Immunization (NACl). Summary of the NACI Update on Immunization in Pregnancy with Tetanus Toxoid, Reduced Diphtheria Toxoid and Reduced Acellular Pertussis (Tdap) Vaccine. Can Commun Dis Rep. 2018;44(3/4):91-4.

https://doi.org/10.14745/ccdr.v44i34a04

\section{Introduction}

In Canada, pertussis is an endemic and cyclical disease, with peaks occurring at two- to five-year intervals. Although pertussis incidence varies by age group, unvaccinated or under vaccinated infants are at greatest risk of infection and associated complications. Between 2006 and 2015, the average age-specific incidence rates and hospitalization rates were highest among 
infants less than one year of age (71.2 and 33.6 cases per 100,000 population). Between 2006 and 2016, infants less than two months of age accounted for the largest proportion of special care unit (SCU) admissions (40.5\%), followed by infants three to four months of age (21.4\%).

Lack of maternal immunity is assumed to increase an infant's susceptibility to infection, both by increasing the risk of disease in mothers (and subsequent transmission to the infant) and by providing insufficient passive protection through antibody transfer (via the placenta or via breast milk). A recently-conducted serosurvey found that the majority of pregnant women (more than 90\%) in Canada had undetectable anti-pertussis toxin levels. In a 2017 survey of immunization practices in Canada, the majority of provincial and territorial governments reported logistical difficulties with implementing maternal tetanus toxoid, reduced diphtheria toxoid and reduced acellular pertussis (Tdap) vaccine immunization programs during outbreak settings only.

Since the last National Advisory Committee on Immunization (NACl) recommendations were published in 2014, new evidence on the safety and effectiveness of Tdap administration in pregnancy has become available. In accordance with the direction that was provided by the Canadian Immunization Committee, $\mathrm{NACl}$ reviewed the following:

- the burden of pertussis in infants less than 12 months of age

- the safety of maternal immunization with Tdap vaccine in pregnancy

- the efficacy and effectiveness of maternal immunization with Tdap in pregnancy in preventing severe outcomes of pertussis infection in infants less than 12 months of age

- the effects of maternal Tdap immunization in pregnancy on an infant's immunological response to the primary vaccine schedule; and

- the impact of maternal Tdap immunization in pregnancy on long term protection against pertussis in children

The objective of the Statement Update was to provide guidance on maternal immunization in pregnancy as a strategy to reduce disease incidence and severe outcomes (defined as hospitalization or death) from pertussis infection in infants younger than 12 months of age. The full update is available online (1). This article is a summary of the update's key findings.

\section{Methods}

$\mathrm{NACl}$ reviewed evidence on the burden of disease in Canada, vaccine safety and immunogenicity and vaccine effectiveness in jurisdictions that have implemented maternal immunization programs. A total of 59 articles were identified, retrieved and included in the literature review to inform this statement. Epidemiological analysis was conducted using national surveillance data including the Canadian Notifiable Disease Surveillance System (CNDSS), the Immunization Monitoring Program Active (IMPACT) and the Canadian Institute for Health Information Discharge Abstract Database (DAD). The evidence pertaining to the following questions was reviewed and critically appraised:

- Is there a significant difference in local or systemic adverse events for the mother following immunization with Tdap vaccine in pregnancy (all stages) compared with adult immunization outside pregnancy?

- Is there a significant difference in adverse fetal and neonatal health outcomes for the baby following immunization of their mother with Tdap vaccine in pregnancy?

- Is maternal immunization in pregnancy with Tdap significantly more efficacious or effective in preventing severe disease in infants under 12 months of age compared with no maternal immunization in pregnancy?

- Is the immunogenicity of diphtheria, tetanus and pertussis (DTaP) vaccination in children born to mothers immunized with Tdap vaccine in pregnancy significantly different compared with infants born to mothers who were not immunized with Tdap vaccine in pregnancy?

- Does maternal immunization with Tdap in pregnancy significantly impact efficacy or effectiveness of DTaP vaccines in preventing related disease in children younger than four to six years of age? A detailed analysis of the literature was published in a separate NACl literature review (2). An evidence synthesis and overall summary of the literature, along with specific recommendations, were provided in the $\mathrm{NACl}$ Statement Update (1).

\section{Results}

\section{Immunogenicity}

In the majority of reviewed studies, post immunization increases in antibody levels resulted in more than $90 \%$ of women achieving anti-PT levels greater than or equal to $10 \mathrm{IU} / \mathrm{ml}$ at one month following immunization. While no serologic correlate of clinical protection against pertussis currently exists, anti-PT levels greater than or equal to $10 \mathrm{IU} / \mathrm{ml}$ are considered to be protective against severe disease. In infants, maternal immunization was found to result in increased pertussis antibody concentrations, with avidity increasing linearly with time to delivery. In the majority of studies, following the receipt of the fourth DTaP dose after 15 months of age, statistically significant differences in antibody levels and avidity were not observed between infants whose mothers received Tdap in pregnancy and those whose mothers did not receive Tdap in pregnancy.

\section{Safety and effectiveness}

No major maternal or infant safety issues, including pregnancy outcomes, were reported in the reviewed literature. Effectiveness of maternal Tdap immunization in pregnancy was estimated to be over $90 \%$ against pertussis in infants younger than two months of age, with no deaths observed among infants whose mothers received Tdap prior to 36 weeks of pregnancy. Maternal immunization with Tdap in pregnancy also resulted in a reduction in infant disease severity and hospitalization. Vaccine effectiveness was also reported to persist after the receipt of the first three DTaP doses, with immunization in pregnancy resulting in $70 \%$ lower risk of pertussis in vaccinated children whose mothers received Tdap in pregnancy.

\section{Recommendations}

Following the review of available evidence, $\mathrm{NACl}$ issued a recommendation for routine immunization with Tdap vaccine in every pregnancy. Complete details of the literature 
review, rationale and relevant considerations for the updated recommendations can be found in the $\mathrm{NACl}$ Update on this topic (1) and the NACI Literature Review (2).

$\mathrm{NACl}$ recommends that immunization with Tdap vaccine should be offered in every pregnancy, irrespective of previous Tdap immunization history (Strong NACI Recommendation). $\mathrm{NACl}$ concludes that there is good evidence to recommend immunization (Grade A Evidence).

Routine maternal Tdap immunization during pregnancy will provide a more robust and complete protection against pertussis in infants compared to immunization during outbreak settings only. Tdap immunization in pregnancy has been shown to protect nine of 10 infants against pertussis younger than three months of age. No significant safety issues have been detected in the currently available body of scientific literature and no increased risk of serious adverse pregnancy, maternal or infant events have been reported in countries that are routinely offering Tdap vaccine for immunization in pregnancy. Similarly, no serious adverse events have been detected in Canada through Canadian Adverse Events Following Immunization Surveillance System (CAEFIS). There is currently no indication of a clinically significant change in the priming of the immunological memory of infants exposed to higher maternally-derived antibody concentrations following Tdap vaccination in pregnancy. Given the rapid waning of maternal antibody observed in studies, vaccination should be offered in each pregnancy irrespective of immunization history or the interval between pregnancies.

$\mathrm{NACl}$ recommends that immunization with Tdap vaccine should ideally be provided between 27 and 32 weeks of gestation (Strong NACI Recommendation, Grade A Evidence). Evidence also supports providing maternal Tdap over a wider range of gestational ages, and $\mathrm{NACl}$ recommends that it may be provided from 13 weeks up to the time of delivery in view of programmatic and unique patient considerations (Discretionary NACI Recommendation, Grade A/B Evidence).

Immunization should ideally be offered at 27-32 weeks of gestation, which is supported by the strongest safety and effectiveness data. Immunization between 13 and 26 weeks of gestation may also be considered in some situations (e.g., pregnancies with an increased risk of preterm delivery) to allow for longer placental exposure to higher antibody levels and maximization of antibody transfer. While it is preferable that immunization is administered in sufficient time before birth (i.e., four weeks) to allow optimal transfer of antibodies and direct protection of the infant against pertussis, it should be considered until the end of pregnancy in women who have not yet received it, as it has the potential to provide partial protection. If Tdap immunization was provided early in pregnancy (e.g., prior to recognition of pregnancy), it is not necessary to re-immunize after 13 weeks of gestation.

Various options for timing of pertussis immunization are possible; the decision on which option is preferable may depend on the considerations itemized in Table 1, below.
Table 1: Options and considerations for pertussis immunization during pregnancy

\begin{tabular}{|c|c|c|}
\hline Options & Considerations & Decision points \\
\hline $\begin{array}{l}\text { 1. Immunization } \\
\text { at } 27-32 \\
\text { weeks of } \\
\text { gestation }\end{array}$ & $\begin{array}{l}\text { Safety } \\
\text { - Strong safety data in third } \\
\text { trimester } \\
\text { Effectiveness } \\
\text { - Effectiveness data } \\
\text { primarily span vaccination } \\
\text { (27-36 weeks of gestation) } \\
\text { Immunogenicity } \\
\text { - Peak maternal anti- } \\
\text { pertussis antibody } \\
\text { levels are achieved } \\
\text { approximately four weeks } \\
\text { following vaccination } \\
\text { Placental transfer of } \\
\text { maternal antibodies is } \\
\text { optimal in third trimester } \\
\text { Feasibility or acceptability } \\
\text { Could be paired with } \\
\text { routine prenatal visit } \\
\text { during which gestational } \\
\text { diabetes screening is } \\
\text { offered (24-28 weeks of } \\
\text { gestation) }\end{array}$ & $\begin{array}{l}\text { Optimal balance } \\
\text { between safety data, } \\
\text { clinical opportunities, } \\
\text { limited antibody waning } \\
\text { potential, efficient } \\
\text { antibody formation and } \\
\text { placental transfer for } \\
\text { term pregnancies. } \\
\text { This option is supported } \\
\text { by the strongest safety } \\
\text { and effectiveness data } \\
\text { of all the options, and } \\
\text { allows enough time for } \\
\text { the antibody response } \\
\text { to fully develop in } \\
\text { pregnancy. } \\
\text { Vaccination can be } \\
\text { paired with routine } \\
\text { maternal visits, but may } \\
\text { not provide protection } \\
\text { for some preterm births. }\end{array}$ \\
\hline $\begin{array}{l}\text { 2. Immunization } \\
\text { at } 13-26 \\
\text { weeks of } \\
\text { gestation }\end{array}$ & $\begin{array}{l}\text { Safety } \\
\text { - Fewer safety data in } \\
\text { second trimester } \\
\text { Effectiveness } \\
\text { - Effectiveness data not } \\
\text { stratified for immunization } \\
\text { in second trimester } \\
\text { (includes immunization } \\
\text { in both second and third } \\
\text { trimester) } \\
\text { Immunogenicity } \\
\text { Peak maternal anti- } \\
\text { pertussis antibody } \\
\text { levels are achieved } \\
\text { approximately four weeks } \\
\text { following vaccination } \\
\text { Some reports have } \\
\text { shown greater antibody } \\
\text { concentrations in infants } \\
\text { following vaccination at } \\
\text { 13-25 weeks compared } \\
\text { with that seen following } \\
\text { vaccination at more than } \\
\text { or equal to } 26 \text { weeks } \\
\text { Earlier vaccine } \\
\text { administration in second } \\
\text { trimester has been shown } \\
\text { to result in higher antibody } \\
\text { avidity (binding) } \\
\text { Feasibility or acceptability } \\
\text { Could be paired with } \\
\text { routine prenatal visits, } \\
\text { either after detailed } \\
\text { anatomical ultrasound is } \\
\text { reviewed (typically done } \\
\text { 18-22 weeks of gestation) } \\
\text { or when gestational } \\
\text { diabetes screening is } \\
\text { performed (24- } 28 \text { weeks } \\
\text { of gestation) }\end{array}$ & $\begin{array}{l}\text { Safety data are fewer } \\
\text { for second trimester, } \\
\text { and effectiveness data } \\
\text { are not stratified for } \\
\text { immunization during } \\
\text { second trimester. } \\
\text { Second trimester } \\
\text { vaccination increases } \\
\text { clinical opportunities } \\
\text { to offer vaccination } \\
\text { and ensures optimal } \\
\text { antibody formation } \\
\text { and transfer for both } \\
\text { term and preterm } \\
\text { infants. For preterm } \\
\text { deliveries, a narrow } \\
\text { window of opportunity } \\
\text { exists between onset of } \\
\text { significant transplacental } \\
\text { antibody transfer at } 28 \\
\text { weeks and delivery. }\end{array}$ \\
\hline $\begin{array}{l}\text { 3. Immunization } \\
\text { before } 13 \\
\text { weeks of } \\
\text { gestation }\end{array}$ & $\begin{array}{l}\text { Safety } \\
\text { - Limited safety data in first } \\
\text { trimester } \\
\text { Effectiveness } \\
\text { - No effectiveness data } \\
\text { stratified for immunization } \\
\text { prior to } 13 \text { weeks of } \\
\text { gestation }\end{array}$ & $\begin{array}{l}\text { Safety data are limited } \\
\text { before } 13 \text { weeks, and } \\
\text { effectiveness data are } \\
\text { not stratified for first } \\
\text { trimester immunization. } \\
\text { When given early in } \\
\text { pregnancy antibody } \\
\text { may wane before term } \\
\text { delivery. }\end{array}$ \\
\hline
\end{tabular}


Table 1: Options and considerations for pertussis immunization during pregnancy (cont'd)

\begin{tabular}{|c|c|c|}
\hline Options & Considerations & Decision points \\
\hline $\begin{array}{l}\text { 3. Immunization } \\
\text { before } 13 \\
\text { weeks of } \\
\text { gestation } \\
\text { (cont'd) }\end{array}$ & $\begin{array}{l}\text { Immunogenicity } \\
\text { - Maternal antibodies will } \\
\text { start to wane prior to term } \\
\text { delivery } \\
\text { Placental transfer of } \\
\text { maternal antibodies is } \\
\text { minimal prior to third } \\
\text { trimester } \\
\text { Feasibility or acceptability } \\
\text { - If vaccine is administered } \\
\text { prior to detailed } \\
\text { anatomical ultrasound, } \\
\text { fetal anomalies and other } \\
\text { first trimester pregnancy- } \\
\text { related complications may } \\
\text { be misattributed to the } \\
\text { vaccine } \\
\text { The vaccine may not be } \\
\text { considered acceptable } \\
\text { by patients and clinicians } \\
\text { in the first trimester of } \\
\text { pregnancy }\end{array}$ & $\begin{array}{l}\text { There is a risk of adverse } \\
\text { events in pregnancy } \\
\text { being misattributed to } \\
\text { vaccination. }\end{array}$ \\
\hline $\begin{array}{l}\text { 4. Immunization } \\
\text { after } 32 \\
\text { weeks of } \\
\text { gestation }\end{array}$ & $\begin{array}{l}\text { Safety } \\
\text { - Strong safety data in third } \\
\text { trimester } \\
\text { Effectiveness } \\
\text { - Effectiveness data } \\
\text { primarily span vaccination } \\
\text { (27-36 weeks of gestation) } \\
\text { Immunogenicity } \\
\text { - Placental transfer of } \\
\text { maternal antibodies is } \\
\text { optimal in third trimester } \\
\text { - Peak maternal anti- } \\
\text { pertussis antibody } \\
\text { levels are achieved } \\
\text { approximately four weeks } \\
\text { following vaccination } \\
\text { Feasibility or acceptability } \\
\text { - Clinical opportunities for } \\
\text { vaccination exist with } \\
\text { frequent routine prenatal } \\
\text { visits towards the end of } \\
\text { pregnancy }\end{array}$ & $\begin{array}{l}\text { The strongest safety and } \\
\text { effectiveness data are } \\
\text { from the third trimester. } \\
\text { This option may not } \\
\text { allow sufficient time } \\
\text { (i.e., four weeks) for } \\
\text { the development } \\
\text { and transfer of } \\
\text { maternal antibodies } \\
\text { before delivery. Late } \\
\text { immunization will not } \\
\text { provide protection for } \\
\text { most preterm births. } \\
\text { There may be fewer } \\
\text { clinical opportunities to } \\
\text { offer vaccination in late } \\
\text { pregnancy compared } \\
\text { with earlier vaccination. }\end{array}$ \\
\hline
\end{tabular}

\section{Conclusion}

There is now strong evidence to support the $\mathrm{NACl}$ recommendation that immunization with Tdap vaccine should be offered in every pregnancy. This is ideally administered between 27 and 32 weeks of gestation but evidence also supports providing maternal Tdap over a wider range of gestational ages from 13 weeks up to the time of delivery in view of programmatic and unique patient considerations.

\section{Authors' statement}

This statement was prepared by the NACl Pertussis Working Group: Dr. J. Brophy (Chair), Dr. N. Brousseau, Dr. E. Castillo, Dr. N. Crowcroft, Dr. S. Deeks, Dr. I. Gemmill, Dr. S. Halperin, Dr. B. Henry, Dr. M. Naus, Dr. M. Salvadori, Dr. B. Seifert.

\section{Conflict of Interest}

None.

\section{Acknowledgements}

$\mathrm{NACl}$ acknowledges and appreciates the contribution of $\mathrm{S}$. Duchesne-Belanger (Centre for Immunization and Respiratory Infectious Diseases [CIRID], Public Health Agency of Canada [PHAC]), L. Gamble (Health Library), J. Rotondo (CIRID, PHAC), and M. Saboui (CIRID, PHAC) to the statement.

NACI Members: Dr. C. Quach (Chair), Dr. W. Vaudry (Vice-Chair), Dr. N. Dayneka, Dr. P. DeWals, Dr. S. Deeks, Dr. V. Dubey, Dr. R. Harrison, Dr. M. Lavoie, Dr C. Rotstein, Dr. M. Salvadori, Dr. B. Sander, Dr. N. Sicard, Dr. R. Warrington

Former NACI Members: Dr. B. Henry, Dr. I. Gemmil, Dr. S. Marchant-Short, Dr. D. Vinh

Liaison Representatives: Dr. J. Brophy (Canadian Association for Immunization Research and Evaluation [CAIRE]), Dr. E. Castillo (Society of Obstetricians and Gynaecologists of Canada), Dr. A. Cohn (Centers for Disease Control and Prevention, United States), Ms. T. Cole (Canadian Immunization Committee), Dr. J. Emili (College of Family Physicians of Canada), Dr. K. Klein (Council of Chief Medical Officers of Health), Dr. C. Mah (Canadian Public Health Association), Dr. D. Moore (Canadian Paediatric Society), Dr. A. Pham-Huy (Association of Medical Microbiology and Infectious Disease [AMMI] Canada)

Former Liaison Representatives: Dr. J. Blake (Society of Obstetricians and Gynaecologists of Canada)

Ex-Officio Representatives: Dr. (LCdr) K. Barnes (National Defence and the Canadian Armed Forces), Ms. G. Charos (CIRID, PHAC), Dr. G. Coleman (Biologics and Genetic Therapies Directorate, Health Canada [HC]), Dr. J. Gallivan (Marketed Health Products Directorate [MHPD], HC), Ms. J. Pennock (CIRID, PHAC), Mr. G. Poliquin (National Microbiology Laboratory), Dr. T. Wong (First Nations and Inuit Health Branch, HC)

\section{Funding}

The work of $\mathrm{NACl}$ is supported by the Public Health Agency of Canada.

\section{References}

1. National Advisory Committee on Immunization (NACl). Update on Immunization in Pregnancy with Tetanus Toxoid, Reduced Diphtheria Toxoid and Reduced Acellular Pertussis (Tdap) Vaccine [cited 2018 Mar 1]. Public Health Agency of Canada. https://www.canada. ca/en/public-health/services/publications/healthy-living/ update-immunization-pregnancy-tdap-vaccine.html

2. National Advisory Committee on Immunization (NACl). Literature Review on Immunization in Pregnancy with Tetanus Toxoid, Reduced Diphtheria Toxoid and Reduced Acellular Pertussis (Tdap) Vaccine: Safety, immunogenicity and effectiveness [cited 2018 Mar 1]. Public Health Agency of Canada. https://www.canada. ca/en/public-health/services/publications/healthy-living/ executive-summary-literature-review-update-immuniz ation-pregnancy-tdap-vaccine.html 